\title{
Influence of river floods on the humification process in the bottom sediments from the Goczałkowice reservoir
}

\author{
Karolina Czerwieńska ${ }^{1 *}$, Waldemar Szendera², Waldemar Chmielewski ${ }^{2}$ \\ ${ }^{1}$ Pracownia Żywokost Waldemar Szendera ComfreyLab \\ ${ }^{2}$ Institute of Environmental Protection - National Research Institute \\ *Corresponding author's e-mail: karolinaczerwienska@gmail.com
}

\begin{abstract}
Keywords: humification, humic acids, EPR, FT-IR, flood, Goczałkowice Reservoir.
Abstract: The paper presents the results of studies on the influence of the 2010 Vistula flood on the humification process in the bottom sediments of the Goczałkowice Reservoir in southern Poland. Due to its location in the vicinity of farmlands, forests and urbanized areas, the Goczałkowice Reservoir is characterized by amplified and intense humification processes within its sediments. The studies were focused on the determining the influence of the flood wave containing organic and inorganic suspensions on these processes. Humic acids were analyzed using two spectroscopic methods: Electron Paramagnetic Resonance (EPR) and Fourier Transform Infrared Spectroscopy (FT-IR). Application of these methods allowed to determine the values of free radicals and of the g-factor, which are indicators of oxidation, aromatization and maturation of humic acids during the humification process, as well as the value of the 1650/1720 ratio, reflecting the dissociation of the $\mathrm{COOH}$ group to $\mathrm{COO}^{-}$and the formation of complexes of transitional metals with humic acids during the humification process.
\end{abstract}

\section{Introduction}

The influence of floods on the functioning of valley-dammed reservoir ecosystems has not been sufficiently studied yet. Flooding may cause rapid, sometimes irrevocable changes in environmental parameters such as water velocity, content of oxygen dissolved in water, amount of water-suspended matter (Fenske et al. 2001, Lenzia et al. 2000, Tesi et al. 2013, Ibragimov et al. 2010)), or the quality of phyto- and zooplankton in particular parts of the reservoir. It is estimated that the flood wave causes the inflow of large amounts of dissolved compounds (mainly nitrates and phosphates) resulting from algal blooms and the appearance of cyanobacteria in the shallower parts of the reservoir (Godlewska et al. 2003).

The flood wave generates also the transport of alluvial or lacustrine material from the bottom of the channel or water reservoir, thus causing changes in the amount and quality of humic acids (Lenzia et al. 2000, Milligan et al. 2007, Tesi et al. 2013). Intense flow of water to rivers and lakes results in the introduction of farming, communal and industrial pollution (Martinez-Santos et al. 2015). Considerable inflow of organic matter with the flood wave causes changes in the humification processes within the sediments, and thus alterations in the physical and chemical properties of the studied humic acids (Fenske et al. 2001, Godlewska et al. 2003). This paper is focused on the study of the influence of the Vistula flood on the humification processes in the bottom sediments of the Goczałkowice Reservoir.

\section{Object and methods of study}

The Goczałkowice Reservoir (49 $51^{\prime}$ N, 18 $\left.8^{\circ} 52^{\prime} \mathrm{E}\right)$ was constructed in the $1950 \mathrm{~s}$ on the $67^{\text {th }} \mathrm{km}$ of the Vistula River as a reservoir for potable and industrial water for the Upper Silesian Industrial Region as well as a reduction of the flood wave that could develop on the Vistula River. The total volume of the reservoir at maximal backwater is $165.6 \mathrm{hm}^{3}$ and its area is $32 \mathrm{~km}^{2}$. Its maximal length is $12 \mathrm{~km}$ and width $-5 \mathrm{~km}$. In the summer season (June-August) the flood reserve is at the level of $45 \mathrm{hm}^{3}$ and in the remaining months - at $38 \mathrm{hm}^{3}$ (Siudy et al. 2005, Szostak et al. 2005). During the 2010 flood, three flood waves were noted on the Vistula River. The first two waves reached the Goczałkowice Reservoir on the $17^{\text {th }}$ and $19^{\text {th }}$ May 2010, and the third - on the $2^{\text {nd }}$ and $3^{\text {rd }}$ June. During the first flood wave, the inflow was at the level of $544 \mathrm{~m}^{3} / \mathrm{s}$, and during the second wave - at $408 \mathrm{~m}^{3} / \mathrm{s}$, which was linked with intense rainfall in Brenna that occurred between $15^{\text {th }}$ and $19^{\text {th }}$ May. The third flood wave, with an inflow of $200 \mathrm{~m}^{3} / \mathrm{s}$, resulted from intense rainfall in Brenna between $28^{\text {th }}$ May and $3^{\text {rd }}$ June [personal data-GPW Katowice].

The evaluation was based on selected physical and chemical indicators of humic acids extracted from the bottom sediments. Samples for studies were collected by workers of the (GPW) according to Polish standards [PN-ISO 5667-15:2004]. The material was collected in four parts of the Goczałkowice Reservoir prior to and after the 2010 flood: prior to the flood 
on $4^{\text {th }}$ June 2009 (spring 2009) and $28^{\text {th }}$ August 2009 (summer 2009), as well as after the flood on $21^{\text {st }}$ June 2010 (spring 2010) (Fig. 1; Table 1). Sample number 1 was collected in the area of Vistula channel, 3,6 km upstream the dam. Sample number 2 and 3 were collected in south part of the reservoir in littoral zone. Sample number 4 was collected in the deepest zone of the reservoir Goczałkowice.

Humic substances were extracted from the samples of bottom sediments from the Goczałkowice Reservoir using the alkaline extraction method according to IHSS (International Humic Substances Society) procedure. $\left(2.31 \times 10^{17}[\mathrm{spin} / \mathrm{g}]\right)$, and the g-factor was compared to the strong pitch benchmark $(\mathrm{g}=2.0028)$. The infrared spectra were obtained with a FT-IR spectrometer Spektrum One PERKIN ELMER. The samples were prepared as pellets with $\mathrm{KBr}$. The obtained spectra were analyzed using AISN Software Inc. Peak Fit ${ }^{\mathrm{TM}}$ software version 4 , determining the $1650 / 1720$ ratio. The $1650 / 1720$ ratio was calculated by subdividing the area below the Gauss curve with the maximum at 1650 by the area below the Gauss curve with the maximum at 1720 .

\section{Results and discussion}

Based on EPR spectra for humic acids extracted from the bottom sediments of the Goczałkowice Reservoir, the values of the g-factor and free radical concentration have been determined (Fig. 2; Table 2). The obtained values of the g-factor are in the range of 2.0026 to 2.0031 ; they are typical of humic acids extracted from bottom sediments from other water reservoirs and comparable with the values of the g-factor obtained for compost (2.0031-2.0034) and sewage sludge (2.0028-2.0034) (Polak et al. 2011, Polak et al. 2009). The free radical concentrations were lower than the values obtained for humic acids extracted from soils $\left(3 \times 10^{17}\right.$ to $24 \times 10^{17}$ [spin/g]) (Watanable et al. 2005) and similar to the free radical concentration of humic acids extracted from compost, bottom sediments and sewage sludge $\left(0.19 \times 10^{17}[\mathrm{spin} / \mathrm{g}]-5.1 \times 10^{17}\right.$ $[\mathrm{spin} / \mathrm{g}]$ ) (Polak et al. 2009).

The mean values of the g-factor for humic acids extracted from the bottom sediments of the Goczałkowice Reservoir prior to and after the 2010 flood lie within the standard error, whereas the mean values of free radical concentrations for humic acids extracted prior to and after the 2010 flood reflect a significant decrease (Fig. 2 and 3; Table 2). Thus, it may be assumed that changes caused by the flood wave did not influence the value of the g-factor for humic substances extracted from the bottom sediments. Most probably, passing of the flood wave caused a simultaneous increase of the intensity of oxidation processes, enrichment of humic substances in oxygen-containing functional groups (increase of g-factor),

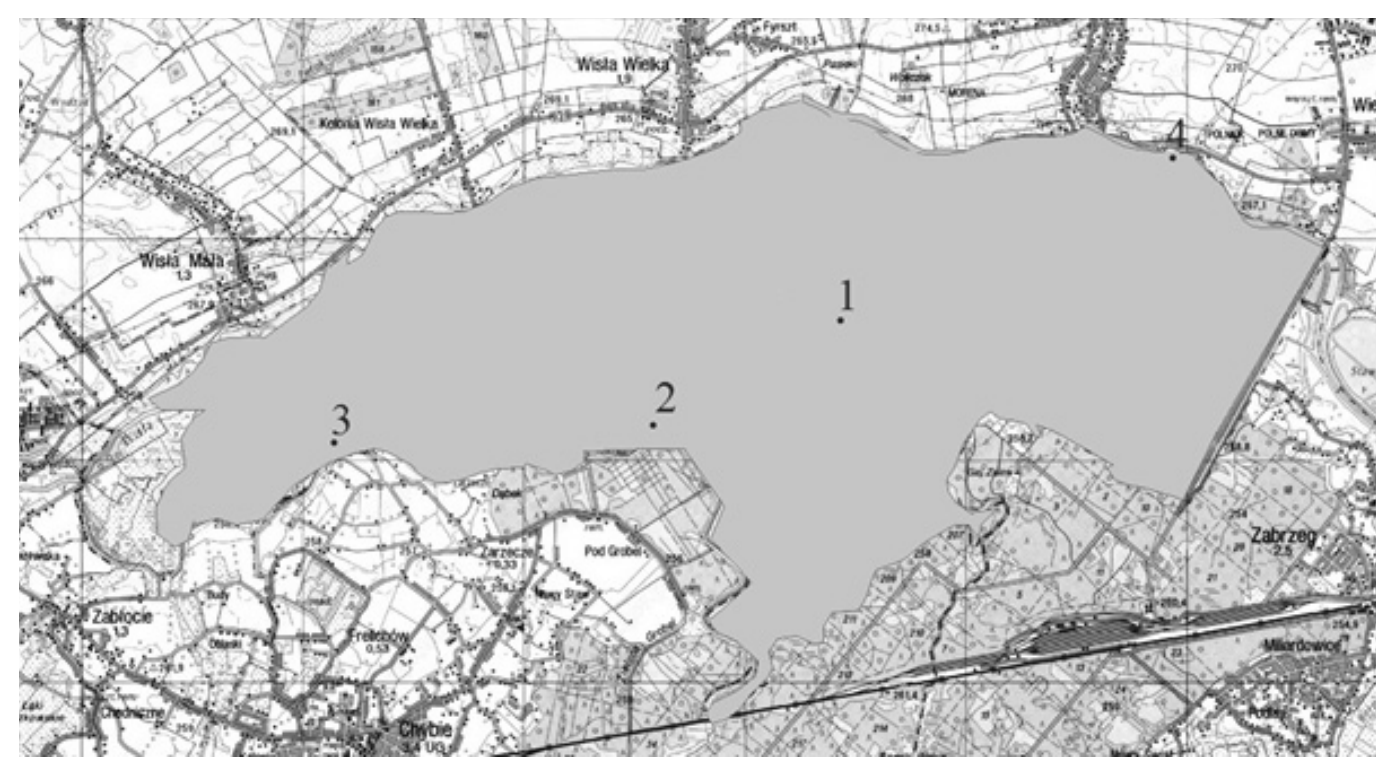

[personal elaboration, source: maps.geoportal.gov.pl]

Fig. 1. Sampling sites of sediments in the Goczałkowice Reservoir

Table 1. Measurement and inspection points in the Goczałkowice Reservoir

\begin{tabular}{|c|c|c|c|c|}
\hline $\begin{array}{c}\text { Sampling site } \\
\text { (no. of sample) }\end{array}$ & Depth & Geographic longitude & Geographic latitude & Measurement and inspection point \\
\hline 1 & $5 \mathrm{~m}$ & $18^{\circ} 53^{\prime} 12^{\prime \prime} \mathrm{E}$ & $49^{\circ} 56^{\prime} 02^{\prime \prime} \mathrm{N}$ & Central part of the Reservoir \\
\hline 2 & $1.5 \mathrm{~m}$ & $18^{\circ} 50^{\prime} 09^{\prime \prime} \mathrm{E}$ & $49^{\circ} 55^{\prime} 17^{\prime \prime} \mathrm{N}$ & Shallow 100 \\
\hline 3 & $1 \mathrm{~m}$ & $18^{\circ} 49^{\prime} 19^{\prime \prime} \mathrm{E}$ & $49^{\circ} 55^{\prime} 26^{\prime \prime} \mathrm{N}$ & Reservoir backflow \\
\hline 4 & $11 \mathrm{~m}$ & $18^{\circ} 54^{\prime} 49^{\prime \prime} \mathrm{E}$ & $49^{\circ} 56^{\prime} 33^{\prime \prime} \mathrm{N}$ & "Goczałkowice" uptake \\
\hline
\end{tabular}


as well as aromatization processes (decrease of g-factor) (Polak et al. 2011, Polak et al. 2007). In turn, the observed decrease of the mean values of free radical concentrations may suggest: a low content of oxygen-containing functional groups, low maturity of humic acids and a larger number of aromatic structures in the studied humic acids. The variability of the free radical concentrations, similarly as in the case of the Odra flood, may be linked with the change of intensity of microbiological processes with the inflow of flood water containing elevated amounts of organic matter, biogenic substances and soil fractions from the drainage basin (Fenske et al. 2001, Mazurkiewicz et al. 1998, Tesi et al. 2013, Ibragimov et al. 2010). Rapid water flow may cause increase of water turbidity, which in consequence leads to changes in the distribution and functioning of zoobenthos in the bottom sediments of the reservoir, a fact that was noted in the case of a flood that passed through the Dobczyce Reservoir in southern Poland (Godlewska et al. 2003).

Table 2. Values of the g-factor and the free radical concentration for humic acids extracted from sediments of the Goczałkowice Reservoir prior to and after the 2010 flood

\begin{tabular}{|c|c|c|c|c|c|c|}
\hline \multirow[b]{3}{*}{$\begin{array}{l}\text { Sampling site } \\
\text { (no. of sample) }\end{array}$} & \multicolumn{3}{|c|}{ g-factor } & \multicolumn{3}{|c|}{ Free radical concentration } \\
\hline & \multicolumn{2}{|c|}{ Prior to the flood } & \multirow{2}{*}{$\begin{array}{c}\text { After the flood } \\
\text { Spring } 2010\end{array}$} & \multicolumn{2}{|c|}{$\begin{array}{l}\text { Prior to the flood } \\
\text { [spin/g] }\end{array}$} & \multirow{2}{*}{$\begin{array}{c}\begin{array}{c}\text { After the flood } \\
\text { [spin/g] }\end{array} \\
\text { Spring } 2010\end{array}$} \\
\hline & Spring 2009 & Summer 2009 & & Spring 2009 & Summer 2009 & \\
\hline 1 & $\begin{array}{c}2.00330 \pm \\
0.00006\end{array}$ & $\begin{array}{c}2.00330 \pm \\
0.00005\end{array}$ & $\begin{array}{c}2.00345 \pm \\
0.00001\end{array}$ & $7.74 \pm 0.02 \times 10^{16}$ & $8.89 \pm 1.10 \times 10^{16}$ & $3.37 \pm 1.39 \times 10^{16}$ \\
\hline 2 & $\begin{array}{c}2.00300 \pm \\
0.00020\end{array}$ & $\begin{array}{c}2.00330 \pm \\
0.00010\end{array}$ & $\begin{array}{c}2.00325 \pm \\
0.00007\end{array}$ & $11.50 \pm 0.50 \times 10^{16}$ & $3.69 \pm 0.65 \times 10^{16}$ & $1.48 \pm 0.86 \times 10^{16}$ \\
\hline 3 & $\begin{array}{c}2.00330 \pm \\
0.00015\end{array}$ & $\begin{array}{c}2.00330 \pm \\
0.00010\end{array}$ & $\begin{array}{c}2.00316 \pm \\
0.00014\end{array}$ & $6.62 \pm 0.53 \times 10^{16}$ & $5.65 \pm 1.08 \times 10^{16}$ & $2.56 \pm 0.21 \times 10^{16}$ \\
\hline 4 & $\begin{array}{c}2.00340 \pm \\
0.00010\end{array}$ & $\begin{array}{c}2.00330 \pm \\
0.00010\end{array}$ & $\begin{array}{c}2.00339 \pm \\
0.00008\end{array}$ & $10.80 \pm 0.02 \times 10^{16}$ & $4.45 \pm 0.10 \times 10^{16}$ & $2.73 \pm 0.87 \times 10^{16}$ \\
\hline Mean \pm SD & $\begin{array}{c}2.00325 \pm \\
0.00017\end{array}$ & $\begin{array}{c}2.00330 \pm \\
0.00009\end{array}$ & $\begin{array}{c}2.00331 \pm \\
0.00013\end{array}$ & $9.17 \pm 2.35 \times 10^{16}$ & $5.67 \pm 2.29 \times 10^{16}$ & $2.54 \pm 0.79 \times 10^{16}$ \\
\hline $\begin{array}{c}\text { Mean prior to } \\
\text { and after the } \\
2010 \text { flood } \pm \text { SD }\end{array}$ & \multicolumn{2}{|c|}{$2.00328 \pm 0.00012$} & $\begin{array}{c}2.00331 \pm \\
0.00013\end{array}$ & \multicolumn{2}{|c|}{$7.42 \pm 2.85 \times 10^{16}$} & $2.54 \pm 0.79 \times 10^{16}$ \\
\hline
\end{tabular}

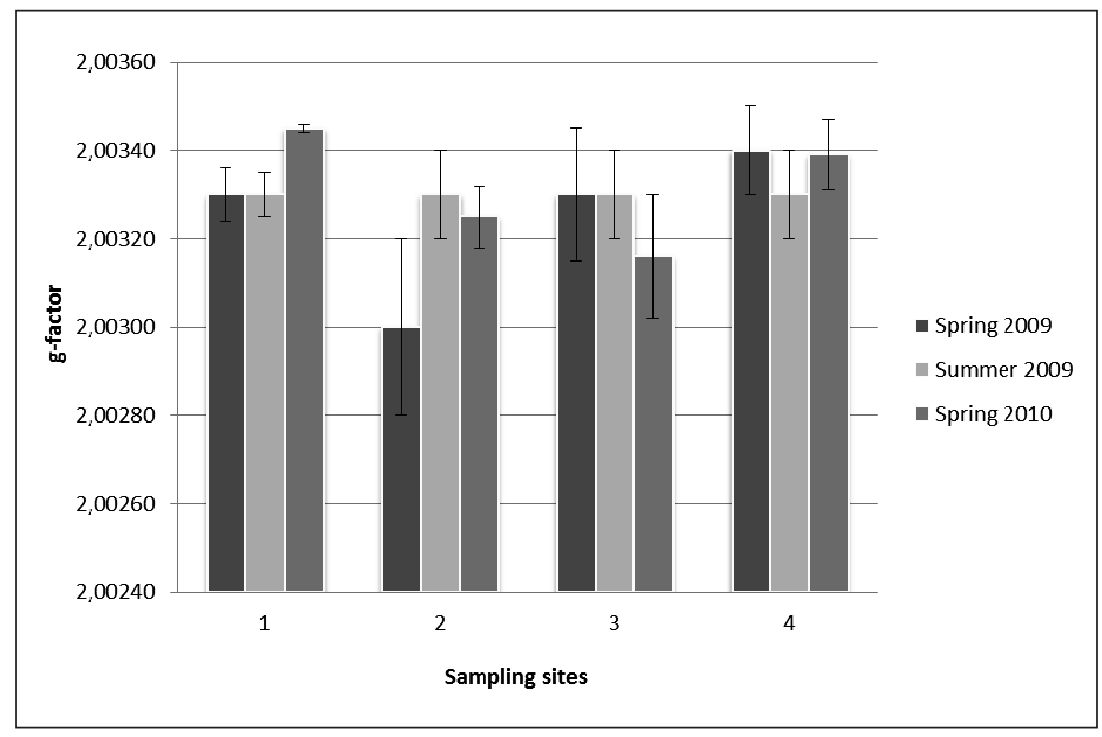

[personal elaboration]

Fig. 2. Values of the g-factor for humic acids extracted from the bottom sediments of the Goczałkowice Reservoir prior to and after the 2010 flood 


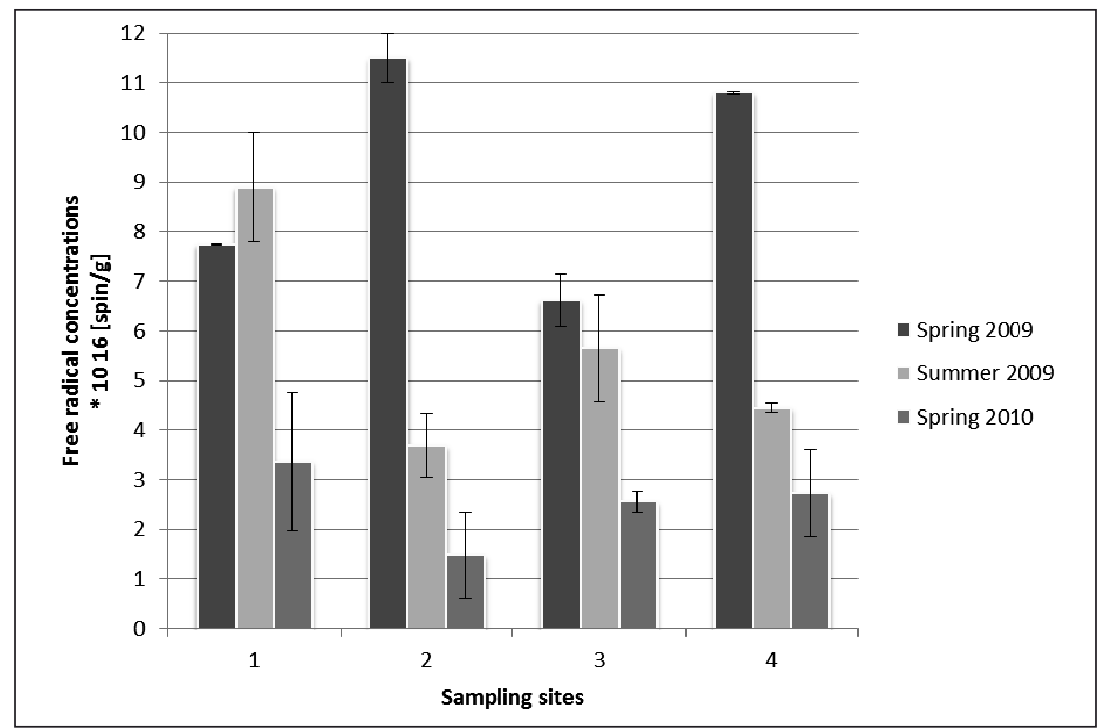

[personal elaboration]

Fig. 3. Values of free radical concentrations for humic acids extracted from sediments of the Goczałkowice Reservoir prior to and after the 2010 flood

Comparison of the determined values of the g-factor for humic acids extracted from the bottom sediments from various parts of the Goczałkowice Reservoir prior to and after the 2010 flood has indicated its slight increase for humic acids extracted from the bottom sediments collected in site 1 (from 2.00330 to 2.00345) (Fig. 2; Table 2). The observed increase of the g-factor may point to the elevated content of the oxygen-containing functional groups in the extracted humic acids (Polak et al. 2009, Polak et al. 2007) and may indicate the intensification of oxygen processes at the expense of aromatization processes in this part of the reservoir (Polak et al. 2011). However, the concentrations of free radicals obtained for this sample indicate a decrease, which in turn points to the limitation of the oxygen processes and inhibition of humification. Due to rapid influx of organic matter e.g. from the flooded areas around the reservoir, the flood wave containing more oxygenated humic acids probably disturbed the upper layer of the bottom sediments, causing deepening of the reservoir and influencing their stability (CzaplickaKotas et al. 2004).

The low values of the g-factor and the free radical concentration for humic acids extracted from the bottom sediments collected in site 3 after the 2010 flood (Fig. 2 and 3; Table 2) may indicate lower maturity of the humic acids and higher content of the aromatic structures within them (Polak et al. 2011, Polak et al. 2007). It seems that increase of humic acids aromatization causes the dislocation of the unpaired electrons of semiquinone radicals between the oxygen atom and aromatic carbon atoms, which in consequence leads to the decrease of the g-factor (Polak et al. 2009). Decrease of the g-factor for humic acids may be caused by the formation of transition metal complexes or the occurrence of these metals in humic acids transported with the flood wave (Ibragimov et al. 2010). It has been evidenced that the presence of lead and mercury complexes may result in the decrease of the g-factor in comparison to values typical of semiquinone radicals i.e. 2.0034 to 1.9999 (Polak et al. 2005). On the other hand, it should be noted that the bottom sediments have different ability to accumulate pollutants from water due to their large sorption capacity and grained size (Martinez-Santos et al. 2015). Fine-grained silt and sediments (silt and clay fraction) have the ability to accumulate greater amounts of pollutants than coarse particles. Clay minerals and organic matter contain higher levels of heavy metals than sandy sediments. (Arifur Rahman et al. 2010, Polak et al. 2007, Fenske et al. 2001, Tesi et al. 2013, Młynarczyk et al. 2013). The analyses of grain size and concentration of heavy metals in bottom sediments were not performed at this stage of research. The lowest free radical concentration and at the same time its largest decrease in comparison to values prior to the flood have been observed for the sample collected in site $2\left(1.48 \pm 0.86 \times 10^{16}[\mathrm{spin} / \mathrm{g}]\right)$. This locality is one of the shallowest within the Goczałkowice Reservoir $(1.5 \mathrm{~m})$, situated near to a peatland reservation to the east from the Zarzecze pump station up to the mouth of the Bajerka stream (Czaplicka-Kotas et al. 2010, Szalińska et al. 2010). Surface waters supplied by groundwater and intense rainfall flow through the marshy peatland contain increased amounts of manganese and iron and cause destabilization of the free radicals content (Czaplicka-Kotas et al. 2010, Czaplicka-Kotas et al. 2004, Polak et al. 2009, Młynarczyk et al. 2013).

Based on the variability of the free radical concentration and values of the g-factor determined from EPR spectra for humic acids extracted from the sediments of the Goczałkowice Reservoir, it can be assumed that the determined free radical concentrations most probably better reflect the changing conditions in the reservoir after the flood because they register a significant decrease. The value of the g-factor practically does not undergo any changes, which may be the consequence of multiple processes. Connection of metals with phenol groups in the humic acids causes shift of the quinon $\leftrightarrow$ hydroquinon equilibrium towards the hydroquinone groups, which results in the decrease of the free radical concentration (Polak et al. 2011).

Analysis of FT-IR spectra for humic acids extracted from the bottom sediments of the Goczałkowice Reservoir prior to and after the 2010 flood confirms the presence of characteristic functional groups. The most crucial information, obtained 
from the FT-IR spectral analysis, is enhancement of the intensity of the band $v_{\mathrm{COO}}^{-}=1650 \mathrm{~cm}^{-1}$ typical of the $\mathrm{COO}^{-}$ group and disappearance of the band typical of non-dissociated carboxylic groups at $v_{\mathrm{C}=\mathrm{O}}=1720 \mathrm{~cm}^{-1}$, which may indicate dissociation of the $\mathrm{COOH}$ group to $\mathrm{COO}^{-}$(Fooken et al. 2003) and the formation of transition metal complexes with humic acids during the humification process (Arifur Rahman et al. 2010, Polak et al. 2007).

The values of the 1650/1720 ratio for humic acids extracted from the bottom sediments collected in four localities in the Goczałkowice Reservoir prior to and after the flood indicate that after the flood, the ratio for humic acids collected in sites 2, 3 and 4 increases, whereas an insignificant decrease is observed in the case of humic acids collected in site 1, during the observation the values g-factor increase. It is not obvious to explain why the values of the 1650/1720 ratio and g-factor are so different, most probably this is caused by the complexity of physical and chemical processes occurring during the passage of the flood wave. This fact of 1650/1720 ratio decrease may be explained as the dissociation of the $\mathrm{COOH}$ group to $\mathrm{COO}^{-}$and the formation of transition metal complexes in the structure of the analyzed humic acids (Table 3; Fig. 5) (Giovela et al. 2004, Polak et al. 2005).

The results of these analyses confirm the suggested influence of metals in samples of the extracted humic acids. Moreover, the results are in concordance with the results of the g-factor and free radicals analysis. Passing of the flood wave has resulted in enhanced influx of metals to the bottom sediments and subsequent formation of metal complexes. Content of transition metals in the flood wave have resulted from the water flow through farming soils containing cadmium and lead and through the area of the peatland reservation, which contains large amounts of iron and manganese (Siudy et al. 2005, Szalińska et al. 2010, Ibragimov et al. 2010). In other reservoirs (Szczecin Lagoon, Dobczyce Reservoir) and rivers (Severn, Po), increased amounts of transition metals were also noted in the bottom sediments after passing of the flood wave, pointing to the inflow of polluted water from areas surrounding the studied rivers and reservoirs (Czaplicka-Kotas et al. 2010, Fenske et al. 2001, Fooken et al. 2003, Zhaoa et al. 1999,

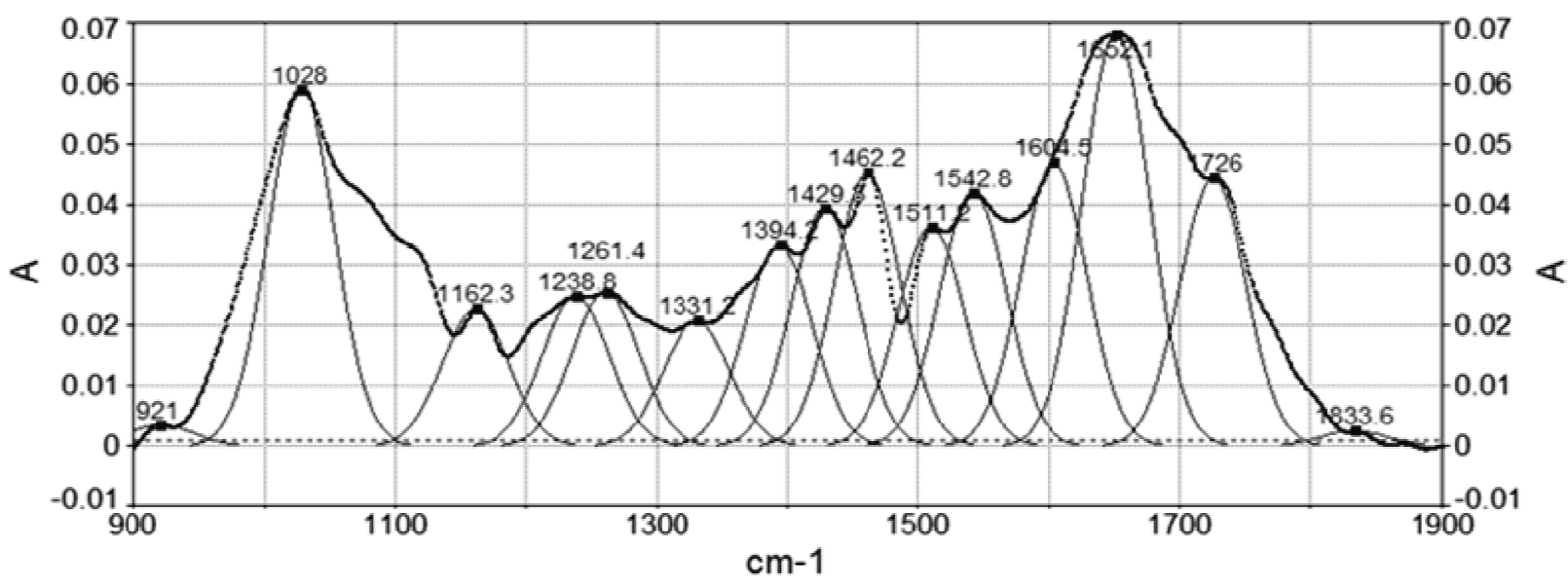

[personal elaboration]

Fig. 4. Distribution of the FT-IR spectra for the humic acid extracted from the sediment collected in sampling site 1 after the flood on the Goczałkowice Reservoir on particular Gaussian amplitudes

Table 3. Values of area (\%) and 1650/1720 ratio for humic acids extracted from the sediments of the Goczałkowice Reservoir prior to and after the 2010 flood

\begin{tabular}{|c|c|c|c|c|c|c|c|c|c|}
\hline \multirow{4}{*}{ 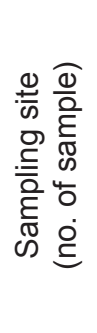 } & \multicolumn{6}{|c|}{ Absorption band } & \multirow{2}{*}{\multicolumn{3}{|c|}{$1650 / 1720$ ratio }} \\
\hline & \multicolumn{3}{|c|}{$\mathrm{v}_{\mathrm{COO}}^{-}=1650 \mathrm{~cm}^{-1}$} & \multicolumn{3}{|c|}{$\mathrm{v}_{\mathrm{C}=\mathrm{O}}=1720 \mathrm{~cm}^{-1}$} & & & \\
\hline & \multicolumn{2}{|c|}{ Prior to the flood } & \multirow{2}{*}{$\begin{array}{c}\begin{array}{c}\text { After } \\
\text { the flood }\end{array} \\
\begin{array}{c}\text { Spring } \\
2010\end{array}\end{array}$} & \multicolumn{2}{|c|}{ Prior to the flood } & \multirow{2}{*}{$\begin{array}{c}\begin{array}{c}\text { After } \\
\text { the flood }\end{array} \\
\begin{array}{c}\text { Spring } \\
2010\end{array}\end{array}$} & \multicolumn{2}{|c|}{ Prior to the flood } & \multirow{2}{*}{$\begin{array}{c}\begin{array}{c}\text { After } \\
\text { the flood }\end{array} \\
\begin{array}{c}\text { Spring } \\
2010\end{array}\end{array}$} \\
\hline & $\begin{array}{l}\text { Spring } \\
2009\end{array}$ & $\begin{array}{l}\text { Summer } \\
2009\end{array}$ & & $\begin{array}{l}\text { Spring } \\
2009\end{array}$ & $\begin{array}{l}\text { Summer } \\
2009\end{array}$ & & $\begin{array}{l}\text { Spring } \\
2009\end{array}$ & $\begin{array}{c}\text { Summer } \\
2009\end{array}$ & \\
\hline 1 & 2.03337 & 2.40168 & 4.34554 & 1.19350 & 1.53070 & 2.82661 & 1.70356 & 1.56901 & 1.53736 \\
\hline 2 & 2.91922 & 2.68572 & 1.74152 & 2.23311 & 2.39907 & 1.27490 & 1.30725 & 1.11949 & 1.36601 \\
\hline 3 & 2.52106 & 2.16262 & 2.25364 & 1.71104 & 1.68589 & 0.87400 & 1.47340 & 1.28277 & 2.57855 \\
\hline 4 & 1.21354 & 2.03240 & 1.71441 & 0.67861 & 1.58360 & 0.96609 & 1.78830 & 1.28341 & 1.77458 \\
\hline
\end{tabular}




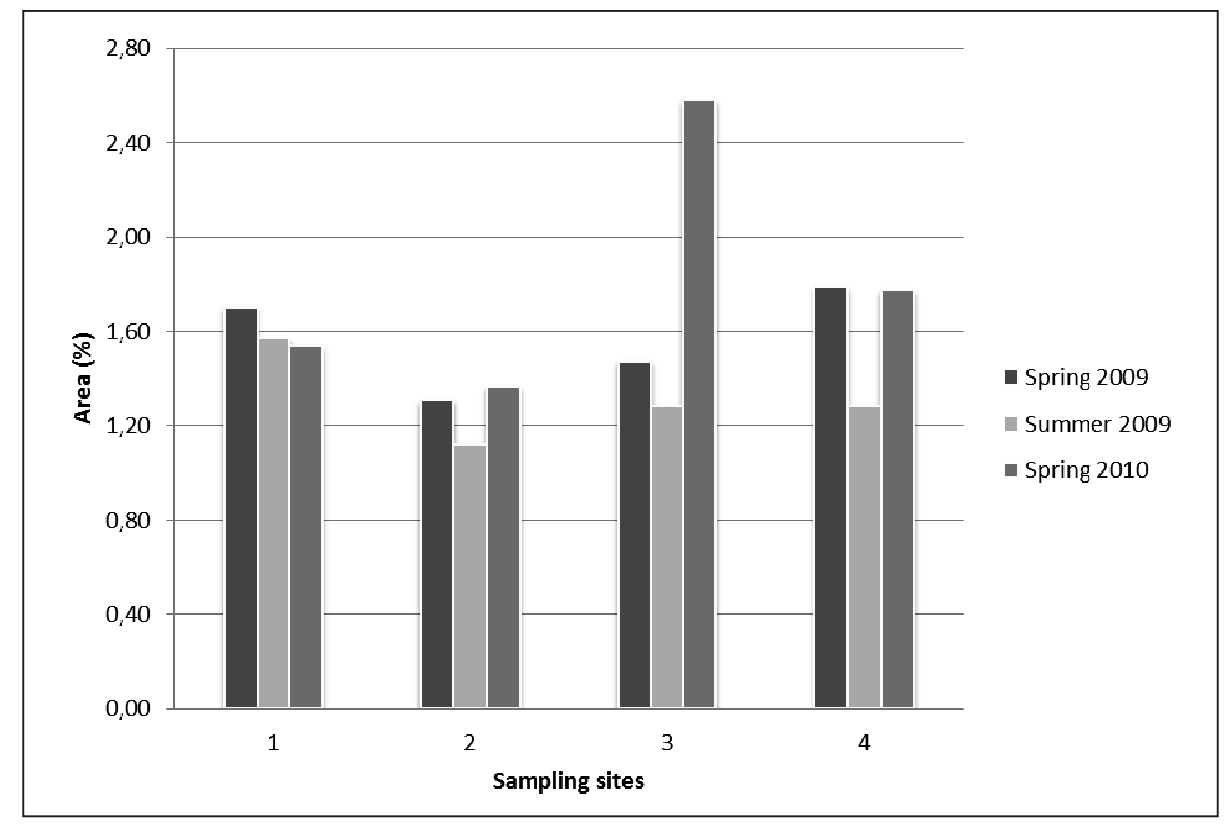

[personal elaboration]

Fig. 5. Values of the $1650 / 1720$ ratio for humic acids extracted from the sediments of the Goczałkowice

Ibragimov et al. 2010). The interaction of heavy metals with humic acids and the effect of particle size on the ability of their accumulation during the passage of the flood wave need further study. The Institute of Environmental Protection, together with its collaborating institutions plan to conduct further research on the processes occurring during the floods.

\section{Summary and conclusions}

It is not clear exactly which physical and chemical processes took place during passing of the flood wave formed on the Vistula River by the Goczałkowice Reservoir, because these are very complex and very dynamic processes, requiring multiannual studies. The conducted spectroscopic analyses of the humic acids extracted from the bottom sediments collected in the Goczałkowice Reservoir prior to and after the flood allow for the following conclusions:

1. Decrease of the free radical concentrations, changes in the values of the g-factor and the 1650/1720 ratio observed after passing of the flood wave indicate the formation of transition metal complexes with humic acids or the occurrence of these metals in the structure of humic acids transported with the flood waters from the flooded area around the Goczałkowice Reservoir.

2. It seems that the variability of organic matter indicators in the Goczałkowice Reservoir after the flood is best reflected by the changes of the free radical concentration, which points to the lower maturity of humic acids from the bottom sediments. This would indicate hampering or rather disturbance of the process with passing of the flood wave.

3. Lack of differences or low variability in the values of the remaining parameters after the flood may result from the simultaneous processes of oxidation and aromatization, which is evidenced by the mutually excluding values of g-factor and free radical concentration.

\section{Acknowledgements}

The paper was based on the results of the study conducted in the Department of Material Chemistry and Chemical Technology, University of Silesia, under the supervision of Dr. Justyna Polak, to whom we are very grateful.

\section{References}

Arifur Rahman, M., Abu Hasan, Md., Rahim, A. \& Shafiqul Alam, A. M. (2010). Characterization of humic acid from the river bottom sediments of Burigonga: complexation studies of metals with humic acid, Pakistan Journal of Environmental and Analytical Chemistry, 11, pp. 42-52.

Czaplicka-Kotas, A., Ślusarczyk, Z., Zagajewska, J. \& Szostak, A. (2010). Analysis of the changes in the content of selected heavy metal ions in water of the Goczałkowice Lake in 1994-2007, Ochrona Środowiska, 32, 4, pp. 51-56. (in Polish)

Czaplicka-Kotas, A., Cwalina, B., Szostak, A., Nogaj, P. \& Ślusarczyk, Z. (2004). Influence of flood on the water quality in the Goczałkowice Reservoir, Czasopismo Techniczne. Środowisko, 8, pp. 49-58. (in Polish)

Fenske, C., Westphal, A., Bachor, E., Breitenbach, E., Buchholz, W., Julich, W.D. \& Hensel, P. (2001). The consequences of the Odra flood (summer 1997) for the Odra lagoon and the beaches of Usedom: What can be expected under extreme conditions?, International Journal of Hygiene and Environmental Health, 203, pp. 417-433.

Fooken, U. \& Liebezeit, G. (2003). An IR study of humic acids isolated from sediments and soils, Senckenbergiana maritima, 32, 1-2, pp. 183-189.

Giovela, M., Parlanti, E., Soriano-Sierra, E.J., Soldi, M.S. \& Sierrae, M.M.D. (2004). Elemental compositions, FT-IR spectra and thermal behavior of sedimentary fulvic and humic acids from aquatic and terrestrial environments, Geochemical Journal, 38, pp. 255-264.

Godlewska, M., Mazurkiewicz-Boro, G., Pociecha, A., Wilk-Woźniak, E. \& Jelonek, M. (2003). Effects of flood on the functioning of the Dobczyce Reservoir ecosystem, Hydrobiologia, 504, pp. 305-313. 
Ibragimov, A., Głosińska, G., Siepak, M. \& Walna, B. (2010). Heavy metals in fluvial sediments of the Odra River flood plains - introductory research, Quaestiones Geographicae, 29, 1, pp. 37-47.

Lenzia, M.A. \& Marchai, L. (2000). Suspended sediment load during floods in a small stream of the Dolomites (northeastern Italy), Catena (Elsevier Science), 39, pp. 267-282.

Martínez-Santos, M., Probst, A., García-García, J. \& Ruiz-Romera E. (2015). Influence of anthropogenic inputs and a high-magnitude flood event on metal contamination pattern in surface bottom sediments from the Deba River urban catchment, Science of The Total Environment, 514, pp. 10-25.

Mazurkiewicz, G. \& Żurek, R. (1998). Direct ecological effects of the July 1997 flood in the case of a river and dammed reservoir, in: Conference Materials, Flood in the Upper Vistula River catchment area in July 1997, Scientific Conference, Cracow, 7-9 May 1998, PAS, Cracow, pp. 195-201.

Milligan, T.G., Hill, P.S. \& Law, B.A. (2007). Flocculation and the loss of sediment from the Po River, Continental Shelf Research, 27, pp. 309-321.

Młynarczyk, N., Bartoszek, M., Polak, J.\& Sułkowski, W.W. (2013). Forms of phosphorus in sediments from the Goczałkowice Reservoir, Applied Geochemistry, 37, pp. 87-939.

Polak, J., Bartoszek, M., Żądło M., Kos, A. \& Sulkowski, W.W. (2011). The spectroscopic studies of humic acids extracted from sediment collected at different seasons, Chemosphere, 84, pp. $1548-1555$.

Polak, J., Bartoszek, M. \& Sulkowski, W.W. (2009). Comparison of some spectroscopic and physico-chemical properties of humic acids extracted from sewage sludge and bottom sediments, Journal of Molecular Structure, 924-926, pp. 309-312

Polak, J., Sułkowski, W.W., Bartoszek, M., Luty, A., Pentak, D. \& Sułkowska, A. (2007). Spectroscopic study of the effect of biological treatment on the humification process of sewage sludge, Journal of Molecular Structure, 834-836, pp. 229-235.

Polak, J., Ziółkowska, A., Bartoszek, M., Maślankiewicz, M. \& Sułkowski, W.W. (2007). Study of the humification process in bottom sediment from Goczałkowice dam reservoir (Poland), Annals of the Polish Chemical Society, pp. 443-446.
Polak, J., Buhl, F., Kita, A., Bartoszek, M. \& Sulkowski, W.W. (2005). The effect of heavy metals on the reduction and stabilisation of the g-factor value of humic acids extracted from sewage sludge, Acta Universitas Latviensis, 692, pp. 121-126.

Polish Standard PN-ISO 5667-15, 2004 (according to ISO 566715:1999)

Siudy, A., Bilnik, A., Świerszcz, T. \& Szlęk, Z. (2005). Multifunctional Goczałkowice Reservoir on Little Vistula and its significance for the Upper Silesia Water Management, in: Conference Materials, Scientific-Technical Conference for the $50^{\text {th }}$ anniversary of the construction of the Reservoir on Little Vistula in Goczalkowice, Pszczyna, pp. 10-21. (in Polish)

Szalińska, E., Koperczak, A. \& Czaplicka-Kotas, A. (2010). Analyses of the heavy metal content in the bottom sediments of the inflows to the Goczałkowice Reservoir, Ochrona Środowiska, 32, 1, pp. 21-25. (in Polish)

Szostak, A. \& Zimoch, I. (2005). Quantitative and qualitative changes of phytoplankton in the Goczałkowice Reservoir in 1992-2004, in: Conference Materials, Scientific-Technical Conference for the $50^{\text {th }}$ anniversary of the construction of the Reservoir on Little Vistula in Goczatkowice, Pszczyna, pp. 124-134. (in Polish)

Szostak, A. \& Zimoch, I. (2005). Quantitative and qualitative changes of phytoplankton in the Goczałkowice Reservoir in 1992-2004, in: Conference Materials, Scientific-Technical Conference for the $50^{\text {th }}$ anniversary of the construction of the Reservoir on Little Vistula in Goczatkowice, Pszczyna, pp. 124-134. (in Polish)

Tesi, T., Miserocchi, S., Acric, F., Langone, L., Boldrin, A., Hatten J.A. \& Albertazzi, S. (2013). Flood-driven transport of sediment, particulate organic matter, and nutrients from the Po River watershed to the Mediterranean Sea, Journal of Hydrology,498, pp. 144-152.

Watanabe, A.D., McPhail, B., Maie, N., Kawasaki, S., Anderson, H.A. \& Cheshire, M.V. (2005). Electron spin resonance characteristics of humic acids from wide range of soil type, Organic Geochemistry, 36, pp. 981-990.

Zhaoa, Y., Marriott, S., Rogers, J. \& Iwugo, K. (1999). A preliminary study of heavy metal distribution on the floodplain of the River Severn, UK by a single flood event, The Science of the Total Environment, 243/244, pp. 219-231.

\section{Wpływ powodzi na rzece Wiśle na procesy humifikacji osadów dennych zbiornika Goczałkowice}

Streszczenie: Przedmiotem artykułu jest przedstawienie wyników badań wpływu powodzi, która miała miejsce na rzece Wisła w 2010 roku na zmianę przebiegu procesu humifikacji osadów dennych Zbiornika zaporowego Goczałkowice, leżącego w południowej części Polski. Zbiornik Goczałkowice, ze względu na swoje położenie oraz obecność obszarów rolnych, leśnych i terenów zurbanizowanych charakteryzuje się wzmożonymi i intensywnie przebiegającymi procesami humifikacji kwasów huminowych zawartych w osadach dennych. Przeprowadzone badania miały na celu określić wpływ fali powodziowej, zawierającej organiczne i nieorganiczne zawiesiny na intensyfikację wyżej wymienionego procesu. Kwasy huminowe badano dwoma metodami spektroskopowymi: elektronowego rezonansu paramagnetycznego (EPR) i spektroskopią w podczerwieni połączoną z transformacją Fouriera (FT-IR). W oparciu o te metody wyznaczono wartości stężenia wolnych rodników i wartości parametru g, stanowiące wskaźnik przebiegu procesów utleniania, aromatyzacji i dojrzewania kwasów huminowych w trakcie procesów humifikacji oraz wartości ilorazu 1650/1720, wskazującego na dysocjację grupy $\mathrm{COOH}^{\text {do } \mathrm{COO}^{-}}$ i tworzenie się kompleksów metali przejściowych. 